\title{
Da fotografia à cultura visual: Arquivo Fotográfico e práticas de preservação do Iphan'
}

Eduardo Augusto Costa ${ }^{2}$

RESUMO: $\bigcirc$ arquivo fotográfico do Instituto do Patrimônio Histórico e Artístico Nacional (Iphan), como instituição de saber científico ligada à arquitetura e ao urbanismo, tem aqui um lugar de reflexão fundamental para a compreensão das práticas de preservação e restauro desenvolvidas pelo próprio instituto. Parte-se do princípio de que um arquivo é o próprio futuro da história, uma vez que é ali onde pesquisadores podem ter acesso ao passado ou, mais precisamente, a uma ideia de passado projetada para o futuro. Mediante um trabalho crítico e investigativo quanto à própria natureza desse arquivo, organizado essencialmente por meio de documentos fotográficos, este artigo pretende apresentar algumas das estratégias do Iphan na operacionalização e projeto de uma história para si, de uma história para a cultura brasileira. Este enfoque busca sinalizar certas questões e possíveis abordagens da cultura visual na sua relação com a historiografia da arquitetura e do patrimônio.

PALAVRAS-CHAVE: Cultura Visual. Fotografia. Patrimônio. Arquitetura.

ABSTRACT: The photo archive of Institute of the Historical and Artistic National Heritage (lphan) as an institution of scientific knowledge related to architecture and urbanism has here a place of reflection for the fundamental understanding of conservation and restoration practices developed by the institute. The starting point is that the archive is the future of history, since it is there where the researchers can have access to the past or, more precisely, to an idea of the past projected into the future. Through a critical and investigative work as to the nature of this archive, organized mainly through photographic documents, this paper presents some of the Iphan's strategies in the operationalization and design of a history to itself, a history to the Brazilian culture. This approach, aims to signalize to certain issues and possible approaches on visual culture, in its relation to the history of architecture and heritage.

KEYWORDS: Visual Culture. Photography. Cultural Heritage. Architecture.
1. Este artigo é uma versão revisada do trabalho Cultura visual e ciência: arquivo fotográfico e as práticas de preservação do Iphan, apresentado no simpósio temático Documentos e arquivos da História da Arquitetura e da Cidade: problemas e métodos, realizado durante o III Enanparq (2014).

2. Bolsista de pós-doutorado PNPD/Capes no Instituto de Filosofia e Ciências Humanas (IFCH) / Universidade Estadual de Campinas (Unicamp). Email: <eduardocosta01@ gmail.com>. 
3. Para facilitar a leitura, utilizarei sempre a designação Iphan - Instituto do Patrimônio Histórico e Artístico Nacional - por ser esta a utilizada em tempo presente. As outras designações serão utilizadas quando se tratar de citação ou forem fundamentais para $o$ entendimento de fatos específicos, como portarias ou decretos. Da mesma maneira, utilizarei Superintendência - para os núcleos regionais do Iphan em cada estado, e não distrito, como antes se designava -, assim como superintendente e não diretor.

4. A produção bibliográfica de Gilberto Ferrez associada à fotografia ganhou fôlego a partir de 1976 , quando realizou uma exposição nos Estados Unidos, ao lado de Weston J. Naef (FERREZ; NAEF, 1976.)
Introdução

A criação e os trabalhos do Instituto do Patrimônio Histórico e Artístico Nacional (lphan) ${ }^{3}$ são temas recorrentes de pesquisas e investigações científicas brasileiras, que reconhecem nesse instituto um papel estruturante na organização e manutenção de um projeto cultural para o país. Trabalhos como o de Silvana Rubino, As fachadas da história (RUBINO, 1991), ou o de Antônio Luiz Dias de Andrade, Um estado completo que pode jamais ter existido (ANDRADE, A. L. D. de, 1993), mostram não só a importância do tema pela sua recorrência, mas, principalmente, a complexidade e a riqueza de abordagens merecidas. Seja a partir de uma reflexão estrutural quanto às ações de preservação realizadas, priorizando certas narrativas e periodizações, seja por meio das escolhas específicas quanto às ações de restauro de algumas edificações ou até mesmo quanto à maneira como o lphan operacionalizou alguns desses restauros, esses trabalhos demonstram a multiplicidade e a importância dos debates em torno do patrimônio.

Parece oportuno, nesse sentido, debater como alguns procedimentos internos e particulares ao Iphan podem propor novas perspectivas de debate e investigação. Não se trata, portanto, de revisitar aquilo que esse instituto oferece aos seus leitores, especialistas ou não, como patrimônio tombado enquanto narrativa objetivada e pretensamente estável. Trata-se de avaliar as estruturas internas, responsáveis pela manutenção de escolhas, narrativas e discursos relativos a este instituto. É nesse sentido que uma reflexão quanto ao arquivo fotográfico do Iphan e a sua visualidade pode contribuir com a historiografia da arquitetura dedicada ao patrimônio brasileiro, iá que esse arquivo assume um papel-chave no processo cotidiano de trabalho interno, assim como é estrutural na mediação com seus agentes externos, sejam eles os fotógrafos, responsáveis pela produção dessa documentação, ou mesmo a própria população, que se familiariza com esse patrimônio, em grande medida, pela mediação com esse suporte documental. Assim, pensar sobre o arquivo desta instituição, sobretudo por meio de seus documentos visuais e fotográficos, remete a uma maneira de se tratar e fazer história.

A avaliação do funcionamento do Iphan, considerada a partir de seu arquivo fotográfico, coloca em debate, primeiramente, o uso de fontes visuais para se pensar a arquitetura, na sua relação com o patrimônio. Essa associação não é nova, podendo-se identificar, no caso da fotografia, uma particular aproximação logo após a sua divulgação na primeira metade do século XIX (PARE, 1982). Quanto ao Brasil, as iniciativas em torno da fotografia, na sua relação com o patrimônio, são significativas a partir da primeira metade do século XX, quando as instituições dedicadas ao patrimônio surgem no país. Nesse sentido, vale destacar a singular contribuição do historiador Gilberto Ferrez - membro do Instituto Histórico e Geográfico Brasileiro (IHGB) e da Associação Brasileira de Críticos de Arte $(A B C A)$, além de conselheiro do Iphan -, responsável pela publicação de quase duas dezenas de livros dedicados à iconografia, em especial, das cidades e da arquitetura brasileira, contribuindo com reflexões e procedimentos institucionais. ${ }^{4}$ 
trabalho de Gilberto Ferrez não foi apenas importante para que se pudesse organizar um referencial iconográfico das principais cidades brasileiras. De certo, ainda hoje, os pesquisadores brasileiros têm na sua produção uma ação, um referencial sem igual. Mas é preciso ainda destacar que os trabalhos de Ferrez contribuíram de maneira sensível para as escolhas tomadas pelo Iphan ao longo dos restauros dos monumentos tombados. Um dos casos mais explícitos, nesse sentido, refere-se à publicação de dois livros dedicados ao Paço Imperial e à Praça $X V$, contendo dezenas de mapas, pinturas, aquarelas e fotografias, que serviram de base para as escolhas tomadas durante o restauro realizado pelo Iphan, no início da década de 1980 (FERREZ, 1978, 1984). Outra iniciativa que vale ser destacada, no caso brasileiro, refere-se à criação do Laboratório de Foto documentação, da Escola de Arquitetura da Universidade Federal de Minas Gerais, no ano de 1954. Sylvio de Vasconcellos, arquiteto modernista e, naquele momento, superintendente do Iphan em Minas Gerais, foi um dos idealizadores e coordenadores de tal laboratório, responsável pela produção de milhares de imagens fotográficas relativas, em especial, aos bens históricos das cidades mineiras. Assim, na relação entre fotografia e patrimônio, os arquitetos mineiros puderam não apenas estudar e avaliar a arquitetura barroca de Minas Gerais, mas, ainda, estabelecer um referencial para a sua produção contemporânea.

Se em meados dos anos 1950 a fotografia já havia encontrado seu lugar privilegiado frente aos estudos e processos dedicados ao patrimônio, é preciso destacar que, entre os anos 1970 e 1990, viria a ocorrer uma verdadeira revolução no campo da fotografia no Brasil. Nesse período, surgem publicações especializadas, organiza-se um conjunto de obras dedicadas à história da fotografia, trabalha-se em torno da definição dos direitos autorais dos fotógrafos e uso legal das fotografias, criam-se de galerias e agências, além de outras tantas iniciativas. Muitos pesquisadores já dedicaram parte de suas investigações à sistematização desses aspectos, o que pode ser verificado de forma singular no artigo Fotografia e História: ensaio bibliográfico, publicado nos Anais do Museu Paulista pelas pesquisadoras Vânia Carvalho, Solange Lima, Maria Carvalho e Tânia Rodrigues (CARVALHO et al., 1994). Ainda que publicado há mais de duas décadas, esta obra mantém-se, ainda hoje, como uma das mais importantes referências às pesquisas dedicadas à história da fotografia. Das obras destacadas pelas pesquisadores, pode-se notar a significativa transformação ocorrida a partir de meados da década de 1970, no que se refere à fotografia e seu diálogo com os mais variados temas e aspectos.

Também no meio acadêmico, a fotografia passou a ocupar lugar de grande interesse desde então, identificando-se a profusão de iniciativas intelectuais que tiveram como ponto de partida a fotografia, explorando de maneira diversa suas características, sobretudo no que se refere à sua visualidade. Teses como a de Boris Kossoy, Elementos para o estudo da fotografia no Brasil no século XIX, defendida em 1979 (KOSSOY, 1979); a de Ana Maria Mauad, Sob o signo da imagem, defendida em 1990 (ESSUS, 1990); ou a de Helovise Costa, Um olho 
que pensa, defendida em 1999 (COSTA, H., 1999), são alguns dos muitos exemplos de trabalhos que passaram a ser desenvolvidos no interior das universidades brasileiras, tendo a fotografia como objeto de investigação de linguagem particular. Ainda no interior das universidades brasileiras, uma série de instituições e núcleos de pesquisa foram criados nesse período, podendo-se destacar o Centro de Memória da Universidade Estadual de Campinas (Unicamp), no ano de 1985, e a Comissão do Patrimônio Cultural da Universidade de São Paulo (USP), criada em 1986 e que posteriormente viria a ser denominada Centro de Preservação Cultural da USP. Ambas as instituições partiam de reflexões em torno da noção de patrimônio cultural, estendendo suas fronteiras para além do patrimônio de pedra e cal, e tinham na fotografia um de seus suportes documentais privilegiados. No caso do Centro de Memória da Unicamp, logo se criou o Arquivo Fotográfico, dedicado à documentação fotográfica das cidades da região de Campinas. Quanto ao Centro de Preservação Cultural da USP, apesar de não haver um órgão responsável exclusivamente dedicado à fotografia, a relação com o tema foi sempre estreita, podendo-se destacar publicações como o volume 8 de seus cadernos, intitulado Registros fotográficos, patrimônio e memória da USP, organizado em 2010 por Maria Lucia Bressan Pinheiro (PINHEIRO, 2010).

O interesse pela fotografia nos estudos acadêmicos logo chegou às faculdades de arquitetura. Inúmeros trabalhos acadêmicos passaram a fazer uso de fotografias e estabeleceram reflexões em torno de seus aspectos, como sinalizado de maneira singular na tese A fotografia e a arquitetura, defendida em 1994 por Cristiano Mascaro (MASCARO, 1994). O caso de Cristiano Mascaro é ainda mais particular, na medida em que se tratava de um reconhecido fotógrafo de reportagens com importante participação nos meios impressos brasileiros. Nesse sentido, o reconhecimento do fotógrafo autor, naquele período, parece também passar pelo reconhecimento do fotógrafo intelectual, teórico de seu objeto de trabalho. $O$ lugar da fotografia, em especial na Faculdade de Arquitetura e Urbanismo da Universidade de São Paulo (FAUUSP), ganha também outros significados quando o fotógrafo foi convidado pelo professor Nestor Goulart para que coordenasse o recém-criado Laboratório de Recursos Audiovisuais da USP, no ano de 1973, implementado com o objetivo de atender à comunidade acadêmica em seus mais variados suportes audiovisuais (DWORECKI; MORAES, [s.d.]). É certo que não se tratava apenas da fotografia, mas também de outros suportes documentais, como o vídeo, em projeção naquele momento.

As publicações dedicadas à fotografia, na sua relação com as cidades e a arquitetura, tiveram também grande espaço a partir dos anos 1980. Os livros de Benedito Lima de Toledo, no Âlbum iconográfico da Avenida Paulista (TOLEDO, 1987); ou o de Nestor Goulart Reis Filho, em Aspectos da história da engenharia civil em São Paulo: 1860-1960 (REIS FILHO, 1989), são alguns dos importantes exemplos em que a fotografia é alçada como protagonista. No entanto, especialmente nesse último título, a fotografia ainda aparece como mera iconografia ou ilustração de certas realizações da engenharia civil de São Paulo, o que, em 
certa medida, também se pode identificar no trabalho de Benedito Lima de Toledo, apesar de um melhor entendimento de seu valor documental. Trata-se, é certo, de uma evidência de que, naquele período, havia uma certa indefinição quanto ao lugar e à importância da fotografia frente às pesquisas acadêmicas. $\bigcirc$ poder sedutor das fotografias devido a sua associação com um passado fazia que seu uso se desse de maneira ainda um tanto desarmada, fomentando um desejo de se ver e consumir imagens, dentro e fora das universidades.

O valor atribuído às fotografias fez que alguns pesquisadores passassem a se dedicar à elaboração de livros e artigos que pudessem dar conta da complexa relação entre a fotografia e o fazer histórico, indicando potencialidades, problemas e abordagens da fotografia enquanto documento. Trabalhos como o de Boris Kossoy, A fotografia como fonte histórica, de 1980 (KOSSOY, 1980); o de Carlos Eugênio de Moura, Retratos quase inocentes, de 1983 (MOURA, 1983); o de Annateresa Fabris, Fotografia: usos e funções no século XIX, de 1991 (FABRIS, 1991); ou o de Etienne Samain, O fotográfico, de 1998 (SAMAIN, 1998), são algumas dessas iniciativas que procuraram discorrer e melhor definir metodologias e abordagens associadas à fotografia em pesquisas acadêmicas e reflexões históricas. Kossoy foi também o responsável por um artigo, publicado na obra História geral da arte no Brasil de Walter Zanini (KOSSOY, 1983), em que apresentava certas características e abordagens da fotografia de sua invenção ao contexto contemporâneo, como A invenção da fotografia; A documentação fotográfica; Fotoclubismo no Brasil; $O$ ensino da fotografia; Fotografia e documentação do patrimônio cultural. O livro organizado por Walter Zanini reserva ainda um significado importante para a história da fotografia não apenas por trazer o trabalho de Kossoy, bastante pioneiro ainda naquele momento, mas, em especial, por colocar a fotografia lado a lado com já consagradas áreas de pesquisa e produção bibliográfica, como a Arquitetura Colonial ou a Arquitetura Barroca. É certo que o trabalho de Walter Zanini trazia outros temas ainda não recorrentes na bibliografia brasileira, como a Arte Contemporânea, o Desenho Industrial, a Comunicação Visual, a Arte Afro-Brasileira, o Artesanato e a Arte-Educação, mas, por esse mesmo motivo, a obra de Zanini é mais uma evidência do lugar que a fotografia passava a ocupar no contexto brasileiro da história da arte.

Outros trabalhos também sistematizaram particularidades ou passagens históricas da fotografia brasileira. $O$ volume 6 da revista Acervo do Arquivo Nacional é uma dessas primeiras referências seminais para a história da fotografia (ACERVO - REVISTA DO ARQUIVO NACIONAL, 1993). De artigos referenciais em torno de fotógrafos do século XIX ou de acervos como o da Biblioteca Nacional, a trabalhos que problematizavam a fotografia como documento histórico e seu papel na relação com a cidade colonial ou moderna, a revista do Arquivo Nacional apresentava um conjunto significativo de caminhos investigativos em torno da fotografia e, assim, logo se tornara um referencial icônico para essa geração dos anos 1990. Publicado no mesmo ano de 1993, o volume 5 do Boletim do Centro de Memória da Unicamp (BOLETIM DO CENTRO DE MEMÓRIA DA UNICAMP, 
1993) também apresentava um conjunto importante de reflexões em torno da fotografia. Para além dos trabalhos que, uma vez mais, dedicavam-se a pensar a fotografia como documento histórico, esse volume trazia ainda reflexões em torno do lugar da fotografia na sua relação entre documento oficial e expressão artística, ampliando seu diálogo com o campo das artes. Por fim, o número 27 da Revista do Patrimônio Histórico e Artístico Nacional dedicado à fotografia (REVISTA DO PATRIMÔNIO HISTÓRICO E ARTíSTICO NACIONAL, 1998) foi talvez uma das mais importantes publicações dos anos 1990, uma vez que estabelecia novos parâmetros de diálogo e investigação, na relação com a fotografia. Neste caso, destaca-se o fato de se tratar de obra publicada pelo próprio Iphan num momento em que o patrimônio cultural já havia ganho espaço no interior da instituição, permitindo assim que temas como o indígena, a cidade, a cidadania e o negro passassem a organizar o centro dos debates de pesquisas e publicações. Nesse contexto, a fotografia ganhava um número especial da revista do Iphan, referendando ações pretéritas, como o pioneiro trabalho de Gilberto Ferrez (FERREZ, 1953), mas também sinalizando para articulações novas como a relação entre fotografia e jornalismo, fotografia e antropologia, fotografia e natureza, a foto pintura e a fotografia na arte pop.

Na arquitetura e no patrimônio, os trabalhos se iniciaram a partir da abordagem da obra de fotógrafos como Marc Ferrez e Augusto Malta, que tiveram destacada participação na documentação das transformações urbanas realizadas pelo prefeito Pereira Passos, no Rio de Janeiro, bem aos moldes da contribuição de Charles Marville durante as remodelações de Haussmann em Paris (PARE, 1982). $\bigcirc$ enfoque dado à obra desses fotógrafos não se dava apenas pela relação que assumiram como fotógrafos oficiais da cidade do Rio de Janeiro num período de sensíveis transformações urbanas na cidade ou pela consequente constituição de uma coleção singular dentre os acervos fotográficos brasileiros. Tratava-se, ainda, de uma valorização do fotógrafo enquanto autor, mobilizado por faculdades artísticas, que bem contribuía para uma narrativa, em certa medida, operativa para os fotógrafos organizados naqueles anos. Ainda dentro dos trabalhos associados à arquitetura, Vânia Carneiro e Solange Lima partiram da obra de Militão Augusto de Azevedo como documentação-chave para a compreensão da formação de uma visualidade para a cidade de São Paulo, articulada com pinturas produzidas sob encomenda do Museu Paulista durante a gestão de Afonso d'Escragnolle Taunay (CARVALHO; LIMA, 1993). Nesse caso, a fotografia servira como iconografia aos pintores, responsáveis por organizar uma imagem idealizada do passado da cidade, procedimento que fora muito utilizado pela Inspetoria dos Monumentos Nacionais (IMN), na década de 1930, muito em função do valor atribuído à pintura no interior dos museus (COSTA, 2015). Essas historiadoras ressignificavam, assim, o lugar da fotografia frente a um determinado contexto social. O livro que se seguiu a esta reflexão, intitulado Fotografia e cidade e publicado em 1997 (LIMA; CARVALHO, 1997), que reuniu as dissertações das autoras voltadas ao estudo de álbuns fotográficos dos séculos XIX e XX, demonstra 
a importância do documento fotográfico para os estudos urbanos, arquitetônicos e patrimoniais e é, certamente, uma referência, ainda hoje, por sistematizar instrumentais de análise formal, temáticas e visuais, além de indicar para questões históricas, como a especialização funcional da cidade. $O$ trabalho dessas historiadoras deu também destaque ao importante gênero de publicações, que viria a ser tratado com acuidade por trabalhos acadêmicos. Tratava-se dos álbuns fotográficos, utilizados especialmente em momentos comemorativos ou de grandes intervenções urbanas por parte dos governos municipais e estaduais (ALMEIDA, 1948; SCHEIER, 1953; GYGAS, 1954).

Simultaneamente aos estudos e pesquisa dedicados à fotografia, no Maranhão, Pará, Pernambuco, Bahia, Minas Gerais e em outros Estados, os institutos e conselhos ligados à preservação do patrimônio passaram a efetuar a catalogação e preservação de seus acervos fotográficos. Tal mobilização foi também motivada por iniciativas promovidas pela Fundação Nacional de Artes (Funarte) e seu Centro de Conservação e Preservação Fotográfica, o CCPF, criado em 1984, o que resultou num grande número ações e publicações dedicadas a divulgar seus arquivos, como se pode notar através de livros como o Catálogo cumulativo do Arquivo Fotográfico do lpac, de 1990 (CATÁLOGO..., 1990); O acervo fotográfico do Departamento de Patrimônio Histórico, de 199210 ACERVO..., 1992); e o livro Arquivos \& coleções fotográficas da Fundação Joaquim Nabuco, de 1995 (ARQUIVOS..., 1995). Pesquisadores passavam a ter contato com acervos até então pouco identificados e catalogados, ou até mesmo ignorados, ampliando o espectro de documentos visuais disponíveis para consulta e desenvolvimento de suas pesquisas. A fotografia, no final dos anos 1990, já se mostrava, em grande parte, consolidada como documento de investigação e reflexão acadêmica brasileira. Assim, os estudos patrimoniais ganharam um novo e importante impulso, mesmo que, por vezes, acabassem por se realizar apenas mediante a ordem do visível, ou por meio da imagem inscrita sobre o suporte documental. $\bigcirc$ uso da fotografia, enquanto documento em si, ainda resvalava numa valorização de uma expressão fotográfica (KOSSOY, 1980) associada a uma valorização do fotógrafo enquanto autor.

No Brasil, essa perspectiva se alterou de maneira profunda por meio de dois textos publicados nos anos 2000, acompanhando uma mudança que vinha ocorrendo internacionalmente, na década anterior. Ulpiano Toledo Bezerra de Meneses publicou, em 2003, um artigo de grande importância teórica, reorientando os estudos históricos para uma cultura visual, em que o real, apresentado pelos documentos visuais bem como pela fotografia, passava a ser tomado como uma elaboração social do visível (MENESES, 2003). Para ele, três questões seriam fundamentalmente importantes para a reflexão histórica: o visual, que trataria dos sistemas de comunicação visual, seus modos de produção, circulação, consumo e ação dos recursos e produtos visuais, além das instituições associadas; o visível, que trata da esfera de poder e controle das imagens; e a visão, que trataria dos instrumentos técnicos, o observador e suas modalidades. De forma correlata, o 
historiador Paulo Knauss (KNAUSS, 2006) também reorientou os estudos ligados aos documentos visuais, sinalizando para a importância da experiência social dos artistas, na formulação das imagens.

Esta breve introdução está longe de sintetizar e organizar a história do uso de documentos visuais e, especialmente, fotografias em trabalhos historiográficos, especialmente no que se refere à arquitetura e à cidade. No Brasil, a utilização de documentos fotográficos é ampla, diversa e bastante heterogênea nas universidades, o que indica para a necessidade de um aprofundamento nas investigações, ainda muito parciais, mesmo frente aos importantes avanços já realizados. Busca-se, no entanto, sinalizar para a significativa mudança ocorrida nos anos 2000, motivada pelos trabalhos de Meneses e Knauss, indicando novos rumos de pesquisa para a historiografia da arquitetura e do patrimônio no Brasil. Os acervos e arquivos fotográficos, muito diversos e numerosos no país, merecem reflexões mais próximas à cultura visual, problematizando seus papéis na formação de uma cultura arquitetônica e patrimonial, que é constitutiva do que se entende hoje por essas disciplinas. Esse cuidado em torno da fotografia, é preciso destacar, refere-se também ao que Leonardo Barci Castriota sinalizou como "redescoberta" das fontes documentais por parte dos pesquisadores dedicados à arquitetura e à cidade (CASTRIOTA, 201 1). Em grande medida, essa redescoberta, segundo o próprio autor, encontra-se associada a uma mudança de sentido no próprio redirecionamento de uma narrativa canônica para uma reflexão crítica à historiografia do movimento moderno. Neste sentido, é expressivo o investimento que historiadores brasileiros e latino-americanos vêm realizando em torno de arquivos - com especial atenção aos fotográficos -, buscando rever pressupostos históricos a partir de seus documentos. Identifica-se nesse processo uma série de instituições dedicadas a organizar e pensar seus arquivos, como o Centro de Documentación de Arquitectura Latinoamericana (Cedodall) ou a Rede Latino-Americana de Acervos de Arquitetura e Urbanismo (Relarq), sinalizando para uma renovação das pesquisas e seus pressupostos.

A abordagem que aqui se pretende realizar sobre o arquivo fotográfico do Iphan remete a uma maneira de vinculá-lo às preocupações teóricas do estudo da cultura visual, muito ligada ao fotográfico, na sua relação com a historiografia da arquitetura e do patrimônio. Mas é certo que essa abordagem se dá, também, na perspectiva assinalada por Castriota, segundo a qual a renovação dos estudos ligados à arquitetura se dá por uma leitura cuidadosa de seus arquivos. Nesse sentido, a apresentação de certas características constitutivas do arquivo fotográfico do Iphan será um modo de sinalizar para algumas questões e possíveis aproximações com tal temática.

Uma cultura visual no Iphan

O Iphan teve, desde sua criação, uma evidente preocupação quanto aos seus documentos. Seja no Anteprojeto elaborado por Mário de Andrade 
(ANDRADE, M. de, 1981) ou no Programa apresentado por Rodrigo Melo Franco de Andrade (ANDRADE, R. M. F. de, 1937), a natureza científica e sistemática das atividades dessa instituição aparecem como traços primordiais ao seu bom desempenho. Mário de Andrade foi meticuloso quanto a essas características, descrevendo ano a ano quais seriam as necessidades e particularidades de sua montagem, implementação e funcionamento. Nesse plano, elaborado para os cinco primeiros anos do serviço, a questão da documentação fotográfica - e também fonográfica e fílmica - aparece com destaque, pois é possível ler as seguintes recomendações: "aquisição, instalação e início de funcionamento dos serviços de filmagem sonora e fonográfica" e "instalação e início do funcionamento dos serviços de fotografia, desenho, aquarelagem e pintura" (ANDRADE, M. de, 1981, p. 49). Ainda no Anteprojeto, Mário de Andrade destaca a necessidade de incorporar "fotografia, ou várias fotografias" na proposta a ser elaborada para o tombamento de toda e qualquer obra. Essa importância atribuída ao documento fotográfico pode ser compreendida na medida em que propõe este e outros suportes como "elementos recolhedores", necessários à não destruição ou à dispersão de "uma escultura, de tal quadro histórico, de um Debret, como dum sambaqui".

Os debates em torno da fotografia seguem de maneira intensa entre Mário de Andrade e Rodrigo Melo Franco de Andrade nos primeiros anos de atividade do Iphan. $\bigcirc$ "problema do fotógrafo" é tratado em detalhes, elaborandose parâmetros de documentação, até a necessidade de produção de cópias fotográficas, a fim de consolidar os arquivos das superintendências regionais e da própria diretoria. Rodrigo Melo Franco de Andrade, atento ao problema, destaca a importância de "uma ação sistemática e continuada com o objetivo de dilatar e tornar mais seguro e apurado o conhecimento dos valores de arte e de história de nosso país" (ANDRADE, R. M. F. de, 1937). O que o então diretor do Iphan parece deixar claro é a existência de um saber por detrás da elaboração e consolidação desse serviço, operacionalizado por meio de ações sistemáticas e contínuas, estabelecendo-se assim um diálogo claro com certas balizas conceituais que configurariam uma atividade padronizada, regular e científica necessária à preservação do patrimônio e ao funcionamento desse instituto. Neste sentido, podese compreender que, se há uma ação estabilizadora vinculada a uma narrativa dominante operada mediante uma política cultural de Estado, o arquivo é estrutura fundamental e reveladora dessa ação, visto que é pela sua definição que se organiza um conhecimento e, finalmente, aquilo que pode ou não ser dito.

A preocupação do lphan em organizar um arquivo de acordo com um discurso cultural não só assinala o seu alinhamento com outras instituições internacionais que privilegiaram a fotografia como suporte documental ligado à história da arte e ao patrimônio, como expõe o caráter moderno desse órgão. No que se refere à história da arte, a trajetória de instituições como o Kunsthistorisches Institut in Florenz (1897), o Bildarchiv Foto Marburg (1913) ou o Arquivo da Hispanic Foundation (1937) demonstram a corrida aos arquivos fomentada pela transformação desse campo disciplinar. Na virada do século XIX para ○ XX, a 
5. Vale destacar que muitos historiadores, antropólogos, filósofos e artistas já se debruçaram sobre a questão do arquivo. Neste sentido, vale ressaltar obras como as de Paulo Ricouer (2007), Elisabeth Roudinesco (2001) e Arlette Farge (1989). fotografia passou a ocupar um lugar decisivo na manutenção de balizas legíveis e compartilhadas por toda a comunidade de investigadores ligados às artes, fazendo dessas instituições centros de referência para as investigações ligadas à fotografia. Já no campo do patrimônio, a relação estabelecida com a fotografia surge desde a invenção desse meio de representação, utilizado precocemente para documentar monumentos, o que realçava o caráter científico desse suporte documental. A chamada mission héliographique, promovida pela Comission des Monuments Historiques, em 1851, foi um dos primeiros e mais importantes empreendimentos fotográficos no que tange à preservação de conjuntos históricos, mesmo tendo constituído um conjunto documental heterogêneo (PARE, 1982). Dessa iniciativa ligada ao patrimônio, nota-se a frequência com que a fotografia se insere nos debates, já na segunda metade do século XIX, como nos trabalhos de Viollet-le-Duc, na França, e os de John Ruskin, na Inglaterra, para citar apenas dois dos mais reconhecidos e, por isso, mais influentes.

Essa preocupação com arquivo fotográfico, aqui exposto por meio de passagens emblemáticas da história do Iphan, em que Rodrigo Melo Franco de Andrade e Mário de Andrade assumem papeis icônicos, localiza não só o caráter moderno assumido pela instituição na preservação de uma cultura nacional, mas também a importância assumida pelos arquivos fotográficos. Os arquivos assumem um papel-chave para a produção da história, na medida em que funcionam como estruturas estabilizadoras de narrativas. Nesse sentido, historiadores, arquitetos, antropólogos ou quaisquer outros pesquisadores, ao recorrerem a um arquivo, enfrentam a sua lógica, a sua estrutura e o seu discurso. Retomando o artigo de Ulpiano Toledo Bezerra de Meneses (MENESES, 2003), ao enfrentar a lógica do arquivo, o pesquisador está diante do visível ou do controle, da esfera de poder por trás de suas imagens e significados. Assim, é possível recorrer ao próprio conceito de arquivo, destacado por Jacque Derrida, quando assinalou que "a questão do arquivo não é, [...] uma questão de passado. [...]. Trata-se da questão do futuro, da questão do futuro por si mesma, da questão de uma resposta, de uma promessa, de uma responsabilidade com o amanhã" (DERRIDA, 1995). ${ }^{5} \bigcirc$ que está, portanto, diante do pesquisador - neste caso, aquele em diálogo com o arquivo fotográfico do Iphan - não é propriamente o passado, mas um projeto elaborado do passado, que visa a ser tomado como uma verdade irredutível em tempo presente. $\bigcirc$ arquivo guarda, portanto, uma intenção, uma verdade elaborada por aqueles que o realizaram e, por isso, o controlam, com um claro objetivo de ser apreendido, em tempo futuro, em acordo com uma determinada narrativa estável e condizente com uma proposta político-cultural.

A reflexão quanto à natureza do arquivo assume, então, um papel-chave para o pensamento em história. Avaliar a sua condição no que se refere à produção, circulação e apropriação dos documentos fotográficos projeta novas balizas para o entendimento de que esse lugar diz respeito a um conhecimento que organiza e controla ideias. Há, portanto, de se investigar a lógica do arquivo, o seu funcionamento, o seu programa enquanto estrutura estabilizadora para, ao 
desarmá-lo, avaliar como essa lógica estabiliza sentidos e regula discursos. Para o caso aqui em questão, equivale a dizer que uma leitura apropriada do arquivo fotográfico do Iphan pode indicar não só as escolhas e narrativas daqueles que organizam os discursos, mas, em especial, como o controle das ideias é operado por meio da lógica do arquivo, desta instituição de saber. É preciso desconstruir a lógica que regulamenta a estrutura de poder associada a esse arquivo, já que, tomando emprestada a observação de Elisabeth Roudinesco, "a obediência cega à positividade do arquivo, a seu poder absoluto, leva tanto a uma impossibilidade da história quanto a uma recusa do arquivo" (ROUDINESCO, 2001 , p. 9). Essa avaliação e desconstrução do arquivo, do saber absoluto e positivista que impõe um discurso é, portanto, matéria de primeira ordem para a reflexão histórica.

arquivo fotográfico do Iphan guarda características singulares e de grande relevância para a compreensão dos sentidos que elabora. Em carta, de 17 de dezembro de 1964, o então diretor da Superintendência paulista do Iphan, Luís Saia, esclarece a organização interna desse arquivo, que conta com a seguinte segmentação: "1 - Documentação Oficial; 2 - Documentação de Pesquisas; 3 Documentação de obras" (SAIA, 1964). Nessa divisão, Luís Saia apresentava uma espécie de estrutura do pensamento da instituição, bem como evidências da própria dinâmica interna de trabalho.

O primeiro dos conjuntos documentais, a "Documentação Oficial", representa o repositório dos documentos fotográficos definitivos dos objetos, dos bens tombados, como esclareceu Luís Saia em carta ao fotógrafo Herman Hugo Graeser (SAIA, 1937). Projetando sobre essa documentação um caráter de primeira ordem, não só para o próprio órgão mas para toda a cultura brasileira, a "Documentação Oficial" seria, portanto, designada para apresentar a visualidade definitiva dos bens tombados pelo Iphan. Ou seja, trata-se do lugar onde se apresenta o estado naturalizado, cristalizado, por meio das ações de restauro do órgão, o lugar onde se tem acesso às características formais, representadas pela visualidade instaurada pelo documento fotográfico, do que seria ou do que deveria ser o bem, patrimônio da cultura brasileira. É somente a partir desses documentos que se pode ter acesso ao patrimônio em seu pretenso estado cristalino, segundo a concepção do Iphan. E, justamente por essa característica, essa documentação destina-se à divulgação e à consulta das provas definitivas dos bens, das características plásticas e formais, definidas pela instituição. Vale aqui destacar que é essa a documentação acessada pelo público, especializado ou não, quando se quer ter acesso à feição original do bem, mas é também essa documentação a acessada pelos próprios técnicos do Iphan, ainda hoje, quando há qualquer necessidade de se realizar um novo restauro no bem, a fim de se restituir suas características definidas pelos técnicos.

Essa característica da "Documentação Oficial" torna compreensível a importância que esse conjunto representa para as ações, em tempo presente, dos técnicos no interior do Iphan, como também para a compreensão do que se faz da cultura nacional, chancelada pelo Ministério da Cultura. De maneira análoga, 
sublinha a importância das ações iniciais dos técnicos sobre o tempo presente, o que dá destaque e conforma o arquivo fotográfico enquanto condição políitica, como resposta estável de um projeto influente sobre um cotidiano presente - um projeto de futuro (CONNERTON, 1989). Compreende-se, portanto, a importância e o cuidado atribuídos a esse conjunto por Rodrigo Melo Franco de Andrade, Mário de Andrade, Luís Saia e Lucio Costa, que souberam controlar - e censurar - aquilo que poderia ou não integrar o arquivo. Tal ação foi realizada em grande medida mediante pedidos encaminhados aos bons fotógrafos que, das conversas, pautas fotográficas e croquis do quadro a ser realizado, produziam imagens pré-elaboradas conceitualmente e condizentes com um discurso que deveriam ratificar visualmente.

A carta de 26 de junho de 1941, escrita pelo fotógrafo Herman Hugo Graeser ao então mestre de obras José Bento e referente à igreja de Nossa Senhora do Rosário da cidade de Embu, é emblemática no que se refere à importância atribuída pelo Iphan à composição da "Documentação Oficial". Nela, Graeser escreve: "Quanto a Embu, peço novamente que você me avise, tão pronto esteja concluído lá o serviço de pintura. É favor não esquecer-se disso, pois que eu sei da facilidade com que aquela pintura branca é sujada pela molecada e depois... tá ruim..." (GRAESER, 1941). A necessidade de o fotógrafo registrar o bem em seu exato momento de inauguração - quando a pintura branca ainda preservava seu estado original e não estava marcada ou desgastada pelas ações do tempo destaca o cuidado e a compreensão do Iphan em consolidar visualmente essa etapa final do processo de restauro, quando, na concepção do Iphan, o bem se encontraria em seu estado original, como se pode ver no documento $n^{\circ} 985$ do arquivo fotográfico da Superintendência do Iphan/SP (Figura 1).

Outra carta escrita pelo fotógrafo Herman Hugo Graeser e encaminhada ao superintendente do Iphan em São Paulo, Luís Saia, revela o cuidado, uma vez mais, dedicado pelo fotógrafo no processo de documentação da arquitetura.

Estou aconselhando vivamente, fazê-la [a viagem para São Sebastião] o quanto antes, pois é de todo aconselhável aproveitar o EXCELENTE tempo que reina agora, porque estou certo que, quando começar a chover, será por certo uma fase longa de chuva e mal tempo. E você sabe que eu, para evitar reclamações posteriores, recuso tirar fotos externas, quando a luz não estiver absolutamente propícia. (GRAESER, 1938)

Essa sinalização indicada pelo fotógrafo Herman Hugo Graeser parece ação muito condizente se pensada nessa relação entre a imagem construída para um fim preciso no interior do arquivo, justamente o da "Documentação Oficial". Evidencia-se, dessa forma, que os erros ou problemas dos documentos produzidos nos primeiros anos não se tratavam propriamente de uma má atuação do fotógrafo, mas de uma característica importante da organização e orientação dos trabalhos de responsabilidade dos técnicos do Iphan. Como explicou Mário de Andrade, em trecho de carta enviada a Rodrigo Melo Franco de Andrade, o trabalho de documentação fotográfica deveria ser segmentado em duas etapas (ANDRADE, M. de, 1937). Na primeira, o fotógrafo realizaria seu trabalho em companhia dos 
técnicos, para, num segundo momento, fazer o restante da documentação em acordo com as orientações fornecidas, bem como em condições ideais de luz. Mesmo que a consideração feita por Mário de Andrade fosse, naquela carta, apenas uma nota de intenção do procedimento de documentação, ela é valiosa para se compreender como os técnicos se relacionavam com o procedimento de feitura das fotografias.

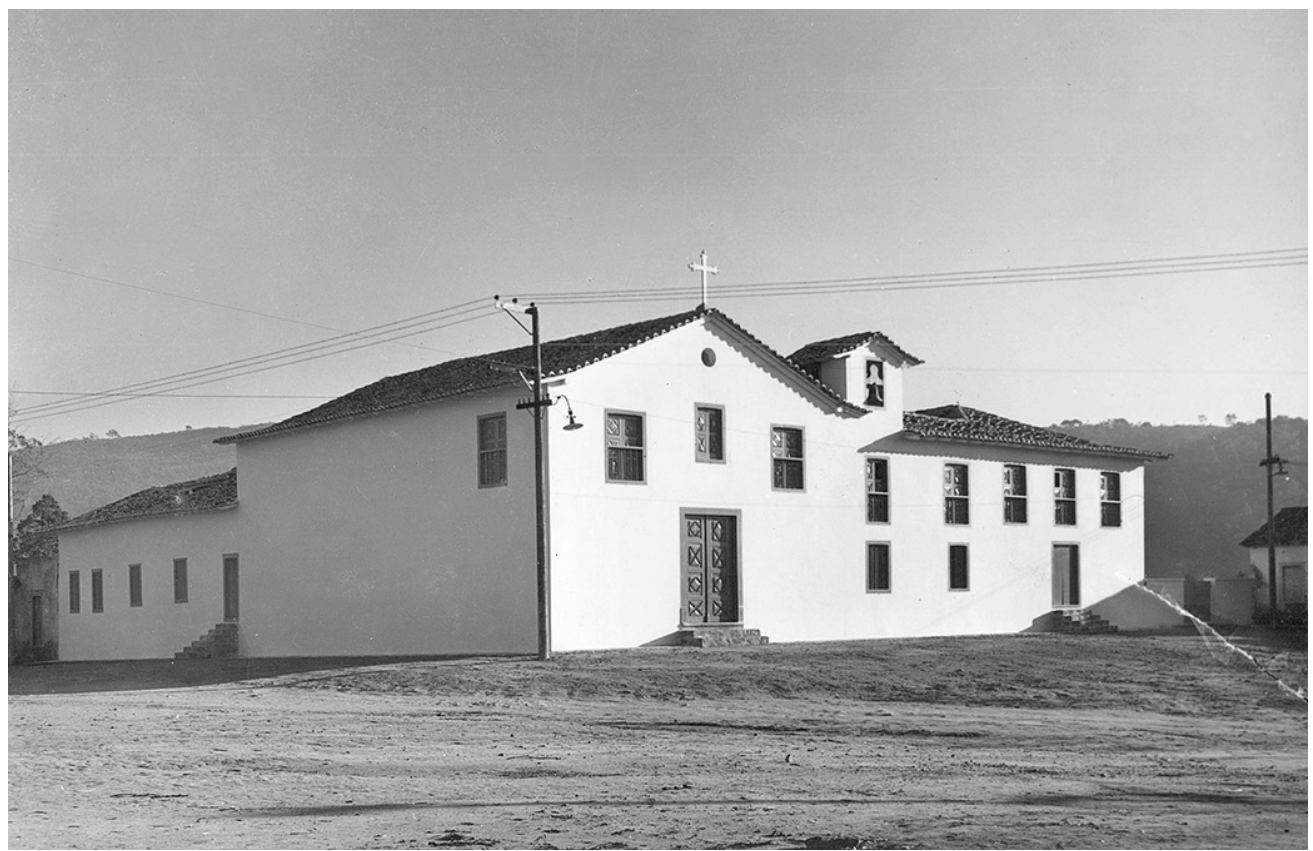

Figura 1: Igreja Nossa Senhora do Rosário - Fachada frontal e lado direito. Fonte: Coleção Oficial n`985 - Herman Hugo Graeser - Arquivo Fotográfico, IPHAN/SP

A ação dos técnicos no controle dos documentos fotográficos ganha corpo, uma vez mais, numa relação estabelecida entre Herman Hugo Graeser e o arquiteto Lucio Costa. Em carta de 10 de agosto de 1946, Rodrigo Melo Franco de Andrade encaminhava o seguinte pedido ao superintendente do Iphan em São Paulo, Luís Saia:

A fim de ilustrar convenientemente o seu artigo na Revista, peço-the mandar com urgência as fotografias indicadas nos croquis anexos, que o Lúcio acaba de fazer. Insista com o nosso amigo Germano para mandar, com toda a presteza, o melhor trabalho que ele puder executar. (ANDRADE, R. M. F. de, 1946)

melhor trabalho que Herman Hugo Graeser poderia executar refere-se não só à qualidade propriamente pictórica do registro, mas, especialmente, à melhor resposta visual da composição, destacada através de croquis realizados por Lucio Costa. ${ }^{6}$ E é de se notar que esse controle do chefe da Direção de Estudos e Tombamentos ganha maiores evidências através de uma carta na qual o próprio
6. Infelizmente, os croquis realizados por Lucio Costa não foram encontrados no arquivo do Iphan/SP. Vale destacar que as fotos solicitadas por Lucio Costa referem-se ao artigo Notas sobre a arquitetura rural paulista do segundo século, de autoria de Luís Saia e publicado no volume n. 8 da Revista do Iphan. Os pedidos de reprodução referem-se, provavelmente, aos documentos realizados em agosto de 1942 - documentos 1499 a 1502 , pertencentes à Documentação Oficial do Arquivo Fotográfico do Iphan/SP. Nota-se, ainda, que, apesar de essa publicação ser relativa ao ano de 1944, ela foi publicada no ano de 1947 (SAIA, 1947). 
diretor do Iphan solicita urgência, no momento em que há a necessidade de se divulgar ao público os trabalhos ou as próprias pesquisas através da Revista do Iphan, o meio de diálogo dessa instituição, não só com o público externo, mas com todos os seus servidores. Nesse sentido, a leitura de que Herman Hugo Graeser teria sido um dos mais importantes fotógrafos do Iphan ganha contornos mais complexos e faz que se indague em que medida se pode afirmar que o gosto é exclusivo do fotógrafo. O gosto parece mesmo vir da capacidade de resposta do fotógrafo às necessidades dos técnicos e, finalmente, do próprio Arquivo Fotográfico às necessidades do Iphan. Trata-se, portanto, da evidência de um trabalho executado entre técnicos e fotógrafos, num diálogo definido "entre" competências. Assim, é natural que tenha havido uma cobrança por parte dos técnicos para que os fotógrafos realizassem boas fotografias capazes de servir ao fim a que destinam, a preservação dos conjuntos tombados. Da mesma forma, a preocupação por parte do fotógrafo é reconhecida como um desdobramento da cobrança que the era feita para a produção de bons documentos para os serviços do Iphan.

A leitura da documentação pertencente a esse primeiro conjunto do arquivo revela com clareza a intenção objetivada do instituto em relação ao restauro das edificações. A visualidade ali preservada refere-se ao estado consolidado e oficial, que passa a ser preservado. A "Documentação Oficial" assegurava portanto, em tempo presente, a perpetuação de uma proposta de restauro, de uma ideia de cultura, projetada para o futuro, já que é essa documentação que seria divulgada e acessada pelos técnicos no momento de futuras intervenções. Torna-se, pois, o registro de identidade do bem.

O segundo conjunto documental, a "Documentação de Pesquisas", revela um caráter um tanto distinto em relação ao primeiro, uma vez que esse não buscava uma imagem final e definidora do bem, mas um primeiro contato, uma primeira abordagem, a fim de fornecer informações iniciais para os técnicos do Iphan. Vale notar que essa documentação não representa a imagem final do bem em seu estado pós-restauro, fazendo que seja pouco acessada pelo público e, de certa maneira, pelos próprios técnicos do Iphan. Essa característica revela, num primeiro momento, que a documentação pertencente a esse conjunto não carrega padrões documentais definidos ou estáveis, mas, ao contrário, representa uma grande heterogeneidade de abordagens e narrativas. Isso pode ser aferido pela grande quantidade de fotografias realizadas por amadores e anônimos, característica presente numa solicitação encaminhada por Rodrigo Melo Franco de Andrade ao jornal $\bigcirc$ Globo, em que pedia aos leitores:

a autor aproveita o ensejo para dirigir um apelo a todos aqueles que, por feliz acaso, possuam fotografias de cidades, prédios, fazendas, engenhos, paisagens, etc., do Brasil, colhidas no século passado, solicitando-thes que comuniquem com ele ou com os museus, bibliotecas, arquivos públicos e especialmente a Diretoria do Patrimônio Histórico e Artístico Nacional, a fim de que se possa empreender o levantamento de quanto ainda existe. (ANDRADE, R. M. F. de, 1987, p. 27) 
Assim, parece, portanto, imprescindível reconhecer que a investigação relativa aos monumentos passíveis de interesse à memória da nação foi, especialmente nos primeiros anos de atividade desse serviço, realizada através de uma dinâmica muito associada à fotografia. A aquisição de documentação fotográfica serviu como estratégia imprescindivel e inerente às escolhas que foram sendo tomadas pelos técnicos, especialmente no que se refere aos tombamentos necessários a serem realizados. Nesse ponto, algumas importantes questões podem ser levantadas quanto a essa característica da documentação.

Os próprios fotógrafos, em muitos casos, foram contratados para, além de realizar a documentação fotográfica, colher informações a respeito de edificações específicas ou mesmo informar quanto à presença de outras que poderiam vir a ser de interesse do Iphan. Atividade que exigia um olhar mais técnico, crítico e treinado quanto aos bens relacionados, o que, gradualmente, alguns fotógrafos foram adquirindo ao tomar contato com as edificações, além do convívio cotidiano com os técnicos desse instituto. ${ }^{7}$ A atividade de informante ao Iphan também foi, em alguns momentos, assumida por Herman Hugo Graeser. Ainda quando contratado como freelancer, o fotógrafo enviava a Luís Saia pequenos relatos de suas viagens, indicando informações de algumas edificações que visitara ou que, por ventura, não tivera acesso, mas que lhe foram indicadas por pessoas locais. Dentre alguns desses documentos arquivados na Superintendência do Iphan em São Paulo, destaca-se uma carta do dia 11 de junho de 1941. Nesse documento, Graeser encaminhou ao Iphan a seguinte informação, destacando que teriam sido fornecidas pelo sr. Octavio Bicudo:

1622 - Havia esta data no umbral da porta, em madeira e ouro. Para saber mais pormenores [falar] com a Família Azambuja. No fim da varanda da casa da fazenda, havia uma capela. O Sino dessa capela está agora na Igreja de Taipa e parece que também outros objetos da mesma capela. (GRAESER, 1941)

A inscrição no umbral da porta, a capela no fim da varanda da casa de fazenda e o sino na lgreja de Taipa são pequenas informações aparentemente simples, mas já muito elaboradas se contrapostas ao que se pode ver e compreender através do que o lphan de São Paulo tombou ao longo das primeiras décadas de sua história. Nesse pequeno trecho descrito por Herman Hugo Graeser, a Casa Bandeirante, tipologia que teve os primeiros estudos realizados por Luís Saia e que foi um dos ícones das comemorações do IV Centenário de São Paulo ISAIA, 1978; LEMOS, 1974; AMARAL, 1981 ), entre outros, parece muito bem representada, o que revela uma certa seleção das informações colhidas ou uma intimidade com o tema por parte de Herman Hugo Graeser. ${ }^{8}$ Em alguns casos, as descrições eram mais detalhadas e, muitas vezes, traziam informações métricas destacadas no ato do registro sobre o próprio suporte documental, bem como eram posteriormente inseridas sobre as ampliações fotográficas.

Essa particularidade da documentação, que faz um contraponto à formalidade plástica e visual controlada pelos técnicos do lphan, revela um aspecto
7. Essa característica dos fotógrafos como informantes de possíveis bens de interesse do Iphan foi descrita, segundo o arquiteto Augusto da Silva Telles, por Alcides da Rocha Miranda, no que se refere ao fotógrafo Marcel Gautherot. Segundo Miranda, Gautherot teria sido o responsável pela descoberta das carrancas do São Francisco (TELlES, 2011, p. 11).

8. Vale destacar que o próprio fato de a Superintendência paulista manter em seu arquivo um documento com características tão ajustadas a questões vinculadas aos estudos e tombamentos realizados em suas primeiras décadas parece revelar, como ponto de partida, as próprias escolhas internas do que é ou não permitido em seu interior. Parece, mais uma vez, tratar-se da própria ação de controle dos técnicos sobre o que se permite ou não como memória, como futuro da instituição. Futuro projetado pelo próprio arquivo. 
não menos importante, já que é justamente mediante essa ausência de controle que se pode verificar a maneira como os técnicos transformaram o bem tombado a fim de se restituir um pretenso estado original. Se comparadas às características formais fornecidas pela "Documentação Oficial" e pela "Documentação de Pesquisa", percebe-se que, em muitos casos, as intervenções realizadas nos bens foram de grandes proporções. Muitas vezes, pode-se observar a destruição completa de campanários, a abertura de portas ou janelas, a retirada de adornos ou mesmo a construção de novos elementos arquitetônicos. Como já destacou Antônio Dias de Andrade, "Tratava-se, pois, de fazer reviver a integridade das formas perdidas, a harmonia originária, tanto mais quanto se abominava o gosto que presidiu as modificações posteriores, marcado pelo abandono das tradições nacionais" (ANDRADE, A. L. D. de, 1993). O conjunto documental preservado no série "Documentação de Pesquisas" revela, portanto, as propostas, ações e intenções dos técnicos do Iphan, que buscavam organizar um conjunto homogêneo e condizente com uma narrativa singularizada pelo colonial, como destacado na fotografia realizada na mesma igreja de Nossa Senhora do Rosário, em Embu, antes de seu restauro (Figura 2). Nesse caso, nota-se perfeitamente o antigo campanário, que viria a ser restituído pela ação do restauro.

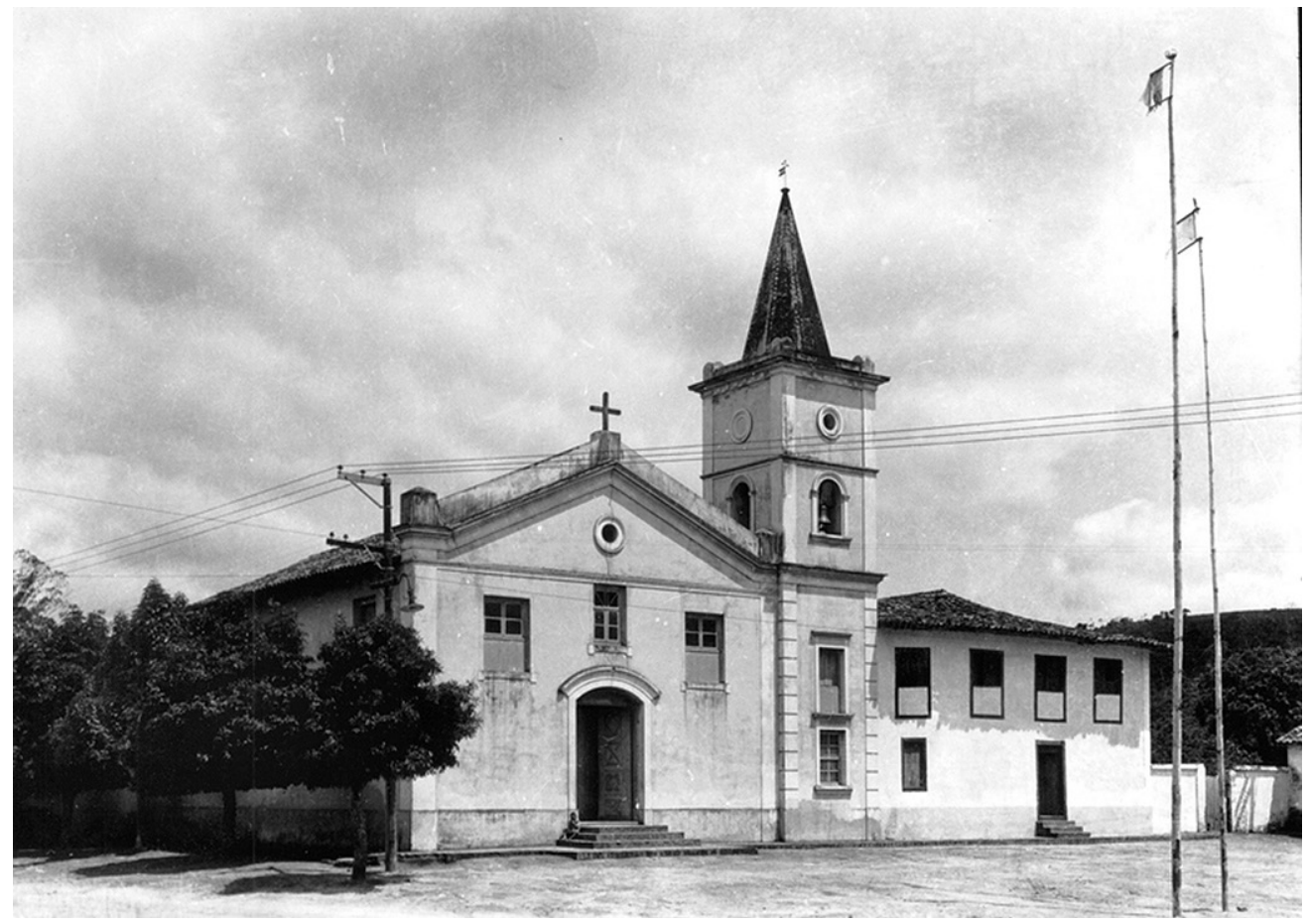

Figura 2: Igreja Nossa Senhora do Rosário - Fachada Frontal. Fonte: Coleção Oficial - neg. Nº 114 - Novembro de 1937 - Herman Hugo Graeser - Arquivo Fotográfico, IPHAN/SP 
Finalmente, o terceiro e último conjunto documental, a "Documentação de Obras", revela uma lógica distinta e particular em relação aos outros conjuntos. Essa documentação tinha objetivos claros quanto ao acompanhamento das obras de restauro. Era, portanto, uma forma de relatar, visualmente, o andamento, o processo e a feitura de pormenores executados no canteiro de obras. Assim, um superintendente podia acompanhar e coordenar atividades simultâneas em distintas localidades, bem como em diferentes cidades, sem precisar se deslocar até o local de uma determinada obra. Dinâmica essa que as próprias Superintendências mantiveram com a Diretoria do Patrimônio, reportando detalhadamente e passo a passo o cotidiano das obras. No entanto, é somente anos depois da criação do Iphan que esses procedimentos foram regulados.

Por meio da circular no 1, de 20 de novembro de 1944, Rodrigo Melo Franco de Andrade estabeleceu a dinâmica de envio de fotografias à Diretoria, no Rio de Janeiro, como norma a ser seguida por todas as Superintendências. Dentre as cinco instruções destinadas à Divisão de Conservação e Restauração, apontavase o seguinte:

Autorizado pelo Diretor do SPHAN o início da obra, deverá o presente remeter o BOLETIM MENSAL DE INFORMAÇÕES, até o dia 5 do mês subsequente, acompanhado dos documentos de despesa (folha de pagamento e recibos do pagamento de material) e fotografias, em duplicata, que identifiquem o andamento da obra [...]. (INSTITUTO..., 1944)

Como exemplo desse processo de interlocução por meio dos documentos fotográficos durante o processo de restauro, pode-se citar a carta de 16 de fevereiro de 1960, escrita por Rodrigo Melo Franco de Andrade e enviada ao fotógrafo Herman Hugo Graeser, em que destacava as seguintes recomendações a serem seguidas na igreja matriz de Itanhaém:

1 - A pintura dos elementos em relevo da frontaria deve ser corrigida, unindo-se numa só faixa o cordão inferior as cimalhas da torre, empena e fachada; 2 - Deve ser completado o trecho faltando da cimalha do terço inferior lateral da torre; 3 - $\bigcirc$ cunhal posterior direito da torre deverá ser seguido até o chão (no caso, com um ressalto de argamassa, a guisa da pilastra); 4 - Os coruchéus deverão ser entonados com os elementos em relevo. (ANDRADE, R. M. F. de, 1960)

As orientações, sempre acompanhadas de documentos fotográficos, eram precisas e bem mostram o controle, ponto a ponto, do processo de restauro dos bens.

Vale aqui destacar que, em paralelo a esse conjunto documental, o Iphan realizou uma série de Cadernos de Obras massivamente ilustrados com fotografias, ${ }^{9}$ desenhos, plantas e anotações técnicas das obras de restauro. Desses cadernos, importa notar a construção narrativa estabelecida por eles, criando um sentido, uma explícita memória técnica e visual do processo de restauro das edificações, um diário das atividades realizadas no canteiro de obras. $\bigcirc$ Caderno no 39 (Figura 3), relativo ao restauro da igreja de São Miguel Paulista em São
9. O número de fotografias que compõem esses cadernos é bastante variado, podendo chegar a 500 fotografias, como no caso do Caderno 28 referente ao restauro das Ruínas de São Miguel no Rio Grande do Sul, localizado no arquivo fotográfico do Iphan. 
Paulo, é um dos mais completos e diversos em informações, bem como único quanto aos recursos utilizados para a construção dessa memória.

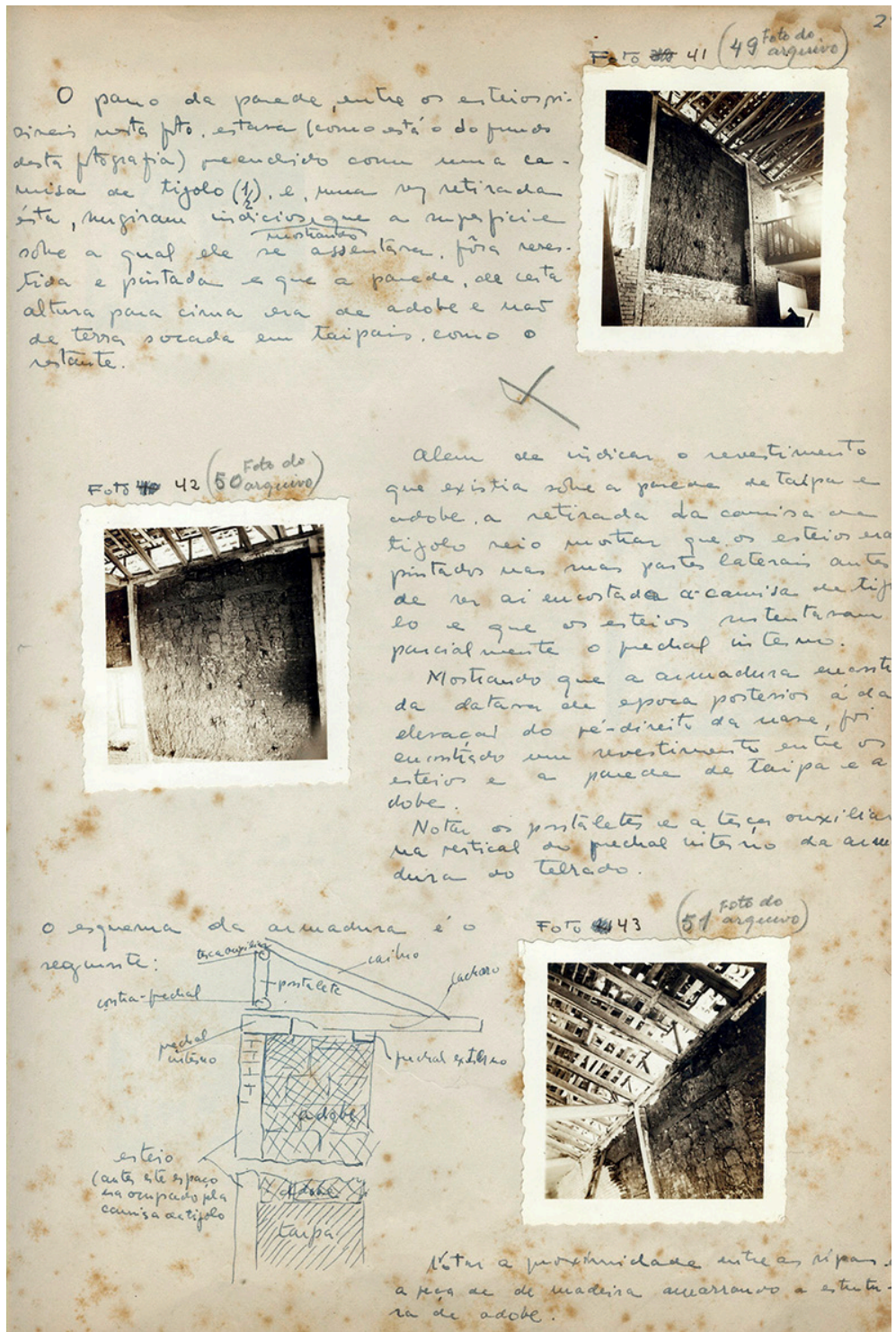

Figura 3: Caderno de Obras n³9 - Igreja de São Miguel Paulista - Obras de recuperação, consolidação e restauração - 19391940 - p.29. Fonte: Arquivo Fotográfico, IPHAN/SP

Características bastante singulares se relacionadas ao fato de que este foi o primeiro conjunto arquitetônico tombado por essa Superintendência, juntamente com a igreja de Mboy e residência anexa na cidade de Embu. Essa característica pertencente a esse caderno parece ressaltálo como exemplar referencial quanto ao que se projetava como ideal para esse suporte, bem como para a própria "Documentação de Obras" do Arquivo Fotográfico do Iphan. Composto por 80 páginas, esse caderno conta com 281 ampliações fotográficas - realizadas a partir de negativos $6 \times 6 \mathrm{~cm}$-, alguns desenhos e, ainda, um volume significativo 
de anotações ricas e detalhadas. Apresentadas quase que majoritariamente em trios de fotografias, cada uma das páginas traz ainda descrições detalhadas da execução de etapas do restauro dessa edificação. Nesse sentido, a página 29 deste caderno apresenta uma descrição bastante detalhada e importante quanto a esse procedimento. Ao lado das duas primeiras fotografias, anotou-se o seguinte:

O pano da parede entre os esteiros visíveis nesta foto estava (como está o do fundo desta fotografia) revestido com uma camada de tijolo (1/2) e uma vez retirada esta, surgiram indícios mostrando que a superfície sobre a qual ele se assentara fora revestida e pintada e que a parede, de certa altura para cima, era de adobe e não de terra socada em taipais como o restante. Além de indicar o revestimento que existia sobre a parede de taipa e adobe, a retirada da camisa de tijolo veio mostrar que os esteios eram pintados nas suas partes laterais antes de ser aí encostada a camisa de tijolo e que os esteios sustentaram parcialmente o frechal interno. Mostrando que a armadura encontrada datava de época posterior a da elevação do pé-direito da nave, foi embutido em revestimento entre os esteios e a parede de taipa e abobe. Notar os pontaletes e a terça auxiliar na vertical do frechal interno da armadura do telhado. (INSTITUTO..., Caderno de Obras n. 39, [s.d.])

texto descritivo, que acompanha as fotografias, estabelece aquilo que a reflexão técnica projeta como narrativa a ser arquivada, memorizada, pela instituição e, finalmente, como cultura brasileira a ser compartilhada. Primeiramente, retirou-se a parede de tijolos, exatamente o elemento característico do século XIX e incongruente com uma história chancelada pelo Iphan (RUBINO, 1991). Ao serem retirados esses elementos, encontraram-se a taipa e o adobe, que caracterizariam uma narrativa mais ajustada com o que essa Superintendência projetou como história para o estado de São Paulo (MAYUMI, 2008). Ainda, os esteios, ao serem liberados parcialmente com a retirada dos tijolos e por trazerem evidências de pintura branca aplicada sobre eles, deram uma característica mais independente ao comportamento estrutural da edificação, o que muito contribui com uma narrativa moderna da edificação em seu funcionamento estrutural, criando, assim, uma ligação do passado tombado com o presente moderno. Se o processo de intervenção e restauro vai sendo construído através da narrativa descrita pelo técnico, a fotografia assume um papel fundamental nessa dinâmica, pois é ela a prova daquilo que se diz no texto e, dessa forma, funciona como baliza que justifica e dá respaldo ao trabalho do técnico. Por outro lado, pode-se dizer que também a fotografia pode enunciar aquilo que se deve escrever, estabelecendo uma ligação intrínseca entre a escrita e a imagem. $\bigcirc$ encadeamento de fotografias cria, portanto, o álibi necessário à intervenção do restauro ou mesmo a justificativa legal daquilo que se deu.

Os procedimentos documentais, tanto em relação à feitura das imagens, como em relação à organização dos arquivos, foram incorporados e interiorizados pelas Superintendências do Iphan. Essas rotinas documentais, bem como a natureza de cada um desses conjuntos que constituem o arquivo fotográfico do Iphan, são temas que não fazem mais parte de um cotidiano de reflexão e investigação desse órgão federal. Eles desapareceram como questão, ao mesmo tempo que passaram 
a ser interiorizados no cotidiano dos trabalhos desenvolvidos pelos técnicos. Tratase, portanto, de um procedimento, uma atividade naturalizada e diária incorporada ao processo de trabalho. Nesse sentido, a invisibilidade e o não questionamento desses procedimentos contribuem para manter intocada, ainda hoje, uma estrutura narrativa da história do patrimônio organizada pelo Iphan, já que, para superá-la, seria preciso não só refletir sobre a história do patrimônio no Brasil, mas, principalmente, sobre a dinâmica contemporânea de trabalho dos servidores dessa instituição e sobre seus arquivos.

Uma vez mais, importa destacar que a documentação fołográfica ocupa um lugar especial no que se refere à documentação, às provas destinadas à preservação dos bens, sendo que esses documentos são controlados e majoritariamente produzidos pelo Iphan, o que é sugerido pela notícia referida d' $O$ Globo. Ao contrário dos documentos cartoriais, relatos, cartas antigas ou até mesmo restos arqueológicos, que ganham importância por testemunharem ações do passado, as fotografias são documentos elaborados contemporaneamente aos estudos e investigações, mas, igualmente, ocupam um lugar de prova no processo de tombamento. Dessa maneira, ao assegurar a lógica do arquivo fotográfico, bem como a dinâmica de trabalho e feitura das fotografias - os documentos visuais -, - Iphan resguarda sua própria narrativa, a sua história, a sua origem, como colocado por Jaques Derrida: "De certa maneira, o termo [arquivo] na verdade, refere-se, como seria correto crer, ao arkhé no sentido físico, histórico ou ontológico, o que significa referir-se ao original, à primeira, à principal, ao primitivo, em suma, ao início" (DERRIDA, 1995).

A leitura de cada um dos três conjuntos documentais responsáveis pela composição do arquivo fotográfico do Iphan - "Documentação Oficial", "Documentação de Pesquisas", "Documentação de Obras" - sugere, assim, um funcionamento de fim comum. Um fim que tem seu sentido cristalizado por meio das fotografias dos bens já restaurados. Dessa forma, é bastante evidente que cada um desses conjuntos tenha sido muito bem considerado e controlado pelos técnicos, garantindo um papel de ordenação dos trabalhos e de difusão da própria Instituição. A memória narrada pelo Iphan tem, portanto, sua matriz potencialmente preservada não só nos edifícios tombados, mediante processos e decretos, ou nos textos divulgados em publicações oficiais. Certamente, há ainda de se considerar o importante lugar ocupado pela visualidade disponibilizada pelo arquivo fotográfico dessa instituição, pois é ela também resultado do controle e do poder dos técnicos, responsáveis pela construção e manutenção de uma memória do patrimônio nacional. $\bigcirc$ arquivo do Iphan guarda a visualidade dessa ação de controle sobre a memória do patrimônio. Por meio da sua "Documentação de Pesquisa" e "Documentação de Obras" pode-se identificar aquilo que o Iphan deixou de restaurar, tombar e, portanto, apagou da memória da Nação, assim como as ações físicas sobre o tectônico que fizerem por resultar no que entendemos hoje como patrimônio histórico e artístico nacional. 
A crítica do arquivo fotográfico do Iphan dá, portanto, destaque ao papel desse arquivo como lugar em potencial para novas reflexões e investigações no que tange à história do patrimônio no Brasil. Ao ser superada a narrativa pretendida por essa instituição por meio de seu arquivo, revelam-se seus problemas, seus ruídos e novos caminhos - uma verdadeira geografia das ideias -, pode, enfim, lançar novas e importantes questões sobre o patrimônio e o que se entende como cultura brasileira.

\section{REFERÊNCIAS}

\section{FONTES PRIMÁRIAS}

ANDRADE, Rodrigo Melo Franco de. [Carta] 10 ago. 1946 [para] SAIA, Luís. Arquivo documental, Iphan/SP.

. [Carta] 16 fev. 1960 [para] GRAESER, Herman Hugo. Arquivo documental, Iphan/SP.

Programa. Revista do Serviço do Patrimônio Histórico e Artístico Nacional, Rio de Janeiro, v. 1, 1937.

Estão roubando o patrimônio artístico do Brasil! In: Rodrigo e o SPHAN. Brasília: MinC; Sphan/ pró-Memória, 1987.

GRAESER, Herman Hugo. [Carta] 18 nov. 1938 [para] SAIA, Luís. Arquivo documental, Iphan/SP.

. [Carta] 26 jun. 1941 [para] BENTO, José. Arquivo documental, Iphan/SP.

INSTITUTO DO PATRIMÔNIO HISTÓRICO E ARTÍSTICO NACIONAL. Caderno 28, referente ao restauro das ruínas de São Miguel, Rio Grande do Sul. Arquivo documental, Iphan/SP.

. Caderno de Obras n. 39, referente ao restauro da igreja de Nossa Senhora do Rosário do Embu, São Paulo. Arquivo documental, Iphan/SP.

Circular n. 1, 20 nov. 1944. Arquivo documental, Iphan/SP.

SAIA, Luís. [Carta] 10 nov. 1937 [para] GRAESER, Herman Hugo. Arquivo documental, Iphan/SP. [Carta] 17 dez. 1964 [para] DIAS, Cândido Lima da Silva. Arquivo documental, Iphan/SP. 
ACERVO - REVISTA DO ARQUIVO NACIONAL. Rio de Janeiro, v. 6, n. 1-2, jan.-dez. 1993.

ALMEIDA, Nelson Martins. Álbum de Araraquara. Araraquara: [s.n.], 1948.

AMARAL, Aracy. A hispanidade em São Paulo. São Paulo: Nobel; Edusp, 1981.

ANDRADE, Antônio Luiz Dias de. Um estado completo que pode jamais ter existido. 1993. Tese (Doutorado) - Faculdade de Arquitetura e Urbanismo da Universidade de São Paulo, São Paulo, 1993.

ANDRADE, Mário de. Anteprojeto de criação do Serviço do Patrimônio Artístico Nacional. In: ___ Mário de Andrade: Cartas de trabalho - correspondência com Rodrigo Mello Franco de Andrade (1936-1945). Brasília: Secretaria do Patrimônio Histórico e Artístico Nacional; Fundação Pró-Memória, 1981.

. Mário de Andrade: Cartas de trabalho - correspondência com Rodrigo Mello Franco de Andrade, 1936-1945. Brasília: Secretaria do Patrimônio Histórico e Artístico Nacional; Fundação Pró-Memória, 1981.

ARQUIVOS \& coleções fotográficas da Fundação Joaquim Nabuco. Recife: Massanguana; Fundaj, 1995.

BOLETIM do Centro de Memória da Unicamp. Campinas, v. 5, n. 10, jul.-dez. 1993.

CARVAlHO, Vânia Carneiro de et al. Fotografia e História: ensaio bibliográfico. Anais do Museu Paulista: História e Cultura Material, São Paulo, v. 2, p. 253-300, jan.-dez. 1994.

; LIMA, Solange Ferraz de. São Paulo antigo, uma encomenda da modernidade: as fotografias de Militão nas pinturas do Museu Paulista. Anais do Museu Paulista: História e Cultura Material, São Paulo, v. 1, p. 147-174, 1993.

CASTRIOTA, Leonardo Barci; ANGELO, Carla Viviane da Silva. As dimensões de um arquivo: recuperando um patrimônio moderno. In: (Org.). Arquitetura e documentação. São Paulo: Annablume; Belo Horizonte: Ieds, 2011.

CATÁLOGO cumulativo do arquivo fotográfico do Ipac. Salvador: Ipac, 1990.

CHUVA, Márcia. Os arquitetos da memória: sociogênese das práticas de preservação do patrimônio cultural no Brasil. Rio de Janeiro: Editora UFRJ, 2009. 
CONNERTON, Paul. How Societies Remember. Cambridge; New York: Cambridge University Press, 1989.

COSTA, Eduardo. Arquivo, poder, memória: Herman Hugo Graeser e o Arquivo fotográfico do Iphan. 2015. Tese (Doutorado) - Instituto de Filosofia e Ciências Humanas da Universidade de Campinas, Campinas, 2015.

COSTA, Helouise. Um olbo que pensa: estética moderna e fotojornalismo. 1999. Tese (Doutorado) - Faculdade de Arquitetura e Urbanismo da Universidade de São Paulo, São Paulo, 1999.

DERRIDA, Jacques. Archive Fever: a Freudian Impression. Chicago: The University of Chicago Press, 1995.

DWORECKI, Silvio M.; MORAES, R. Histórico. FAU USP. [s.d.] Disponível em: < http://www. fau.usp.br/fau/secoes/video/historico/index.html>. Acesso em: 30 abr. 2016.

ESSUS, Ana Maria Mauad de Souza Andrade. Sob o signo da imagem. 1990. Tese (Doutorado) - Universidade Federal Fluminense, Niterói, 1990.

FABRIS, Annateresa (Org.). Fotografia: usos e funções no século XIX. São Paulo: Edusp, 1991.

FARGE, Arlette. Le gout de l'archive. Paris: Seuil, 1989.

FERREZ, Gilberto. A fotografia no Brasil e um de seus mais dedicados servidores. Revista do Patrimônio Histórico e Artístico Nacional, n. 10, Rio de Janeiro, 1953.

A praça 15 de novembro, antigo Largo do Carmo. Rio de Janeiro: Riotur Empresa de Turismo do Município do Rio de Janeiro S.A., 1978.

O Paço da Cidade do Rio de Janeiro. Rio de Janeiro: Fundação Nacional Pró-Memória, 1984.

; NAEF, Weston J. Pionner photographers of Brasil: 1840-1920. New York: Center for Inter-American Relations, 1976.

GYGAS, Theo. Eis São Paulo. São Paulo: Monumento, 1954.

KNAUSS, Paulo. O desafio de fazer história com imagens. ArtCultura, Uberlândia, v. 8, n. 12, p. 97-115, jan.-jun. 2006.

KOSSOY, Boris. Elementos para o estudo da fotografia no Brasil no século XIX. 1979. Tese (Doutorado) - Fundação Escola de Sociologia e Política de São Paulo, São Paulo, 1979. 
A fotografia como fonte bistórica: introdução à pesquisa e interpretação das imagens do passado. São Paulo: Museu da Indústria, Comércio e Tecnologia, 1980.

Fotografia. In: ZANINI, Walter (Org.). História geral da arte no Brasil. São Paulo: Instituto Walter Moreira Salles; Fundação Djalma Guimarães, 1983. p. 867-913. v. 2.

LEMOS, Carlos Alberto Cerqueira. A casa colonial paulista. Revista do Instituto Histórico e Geográfico Guarujá/Bertioga, São Paulo, n. 9, p. 42-43, 1974.

LIMA, Solange Ferraz de; CARVALHO, Vânia Carneiro de. Fotografia e cidade: da razão urbana à lógica de consumo: álbuns da cidade de São Paulo, 1887-1954. Campinas: Mercado das Letras; Fapesp, 1997.

MASCARO, Cristiano. A fotografia e a arquitetura. 1994. Tese (Doutorado) - Faculdade de Arquitetura e Urbanismo, Universidade de São Paulo, São Paulo, 1994.

MAYUMI, Lia. Taipa, canela-preta e concreto. São Paulo: Romano Guerra Editora, 2008.

MENESES, Ulpiano Toledo Bezerra de. Fontes visuais, cultura visual, história visual. Balanço provisório, propostas cautelares. Revista Brasileira de História, São Paulo, v. 23, n. 45, p. 11$36,2003$.

MOURA, Carlos Eugênio Marcondes de (Org.). Retratos quase inocentes. São Paulo: Nobel, 1983.

O ACERVO fotográfico do Departamento de Patrimônio Histórico: processamento técnico e informações. São Paulo: DPH, 1992.

PARE, Richard. Photography and Architecture: 1839-1939. Canada: Canadian Center for Architecture, 1982.

PINHEIRO, Maria Lucia Bressan Pinheiro (Org.). Registros fotográficos, patrimônio e memória da USP. Cadernos CPC, n. 8. Centro de Preservação Cultural da USP. São Paulo: Edusp, 2010.

REIS FILHO, Nestor Goulart. Aspectos da história da engenharia civil em São Paulo: 18601960. São Paulo: CBPO/Kosmos, 1989.

RICOEUR, Paul. A memória, a bistória, o esquecimento. Campinas: Editora da Unicamp, 2007.

ROUDINESCO, Elisabeth. A análise e o arquivo. Rio de Janeiro: Jorge Zahar, 2001.

REVISTA do Patrimônio Histórico e Artístico Nacional. Rio de Janeiro, n. 27, 1998. 
RUBINO, Silvana Barbosa. As fachadas da história: os antecedentes, a criação e os trabalhos do Serviço do Patrimônio Histórico e Artístico Nacional, 1937-1968. 1991. Dissertação (Mestrado) - Instituto de Filosofia e Ciências Sociais, Universidade de Campinas, Campinas, 1991.

Morada paulista. São Paulo: Perspectiva, 1978.

Notas sobre a arquitetura rural paulista do segundo século. Revista do Iphan, v. 8, p. 217-224, 1947.

SAMAIN, Etienne (Org.). O fotográfico. São Paulo: Hucitec, 1998.

SCHEIER, Peter. Paraná Brasil. Paraná: Impressora Paranaense S.A., 1953.

SCHIAVINATTO, Iara Lis; COSTA, Eduardo. Cultura visual E bistória. São Paulo: Alameda Editorial. (no prelo).

TOLEDO, Benedito Lima de. Álbum iconográfico da Avenida Paulista. São Paulo: Ex-Libris, 1987.

Artigo apresentado em 28/03/2016. Aprovado em 27/12/2016. 